\title{
SUBALTERNISM IN OODGEROO NOONUCCAL'S SELECTED POEMS
}

\author{
Wardatul Khoiriyah', Siti Masitoh', Sri Muniroch ${ }^{2}$ \\ ${ }^{1}$ Universitas Islam Negeri Maulana Malik Ibrahim Malang \\ ${ }^{2}$ University of Queensland, Australia \\ 16320030@student.uin-malang.ac.id
}

\section{Abstract}

This study focuses on the subalternism in Oodgeroo Noonuccal's selected poems. The approach used in this research is post-colonial approach, which focused on the context of literary works contained the effects of colonialism both on societies and cultures. The result of this research shows that the selected poems of Oodgeroo are portraying the subalternism in the matter of the superior domination and the effects which illustrate the British superiority that lead to their domination against Aboriginal people as the weaker party and resulting the great predicaments for them. Woman as subaltern which show how Aboriginal women are forced to be slaves to serve and satisfy the lust of British colonists until the end of their lives. Lastly, the voiceless which show how the Aboriginal people must live surrounding by representations and misrepresentations of the privileged parties who hold domination that makes it more difficult for them to get their rights. This research also revealed that Oodgeroo is successfully speak for the Aboriginal people supported with the fact that she is an Aboriginal woman who write poetry to voice her people.

Keywords: post-colonial, spivakian subalternism, aborigines

\section{INTRODUCTION}

Oodgeroo Noonuccal also called as Kath Walker (until 1998) who is regarded as 'poet of the people' due to her work that allows non-Aboriginal readers to step inside into the Aborigines' lives and see why they feel oppressed by the white colonization. She also considered as the first modern-day Aboriginal protest writer and even one of the greatest Australian indigenous poets and activists. Most of her poetry is filled with images of Aboriginal people, which deals with land rights and social justice as the struggles and effects of colonization.

Oodgeroo Noonuccal was born with the original Anglo-Australian name Kathleen Jean Mary Ruska in full on November 3rd, 1920, in Minjerriba (well-known as North Stradbroke Island). In her 44 years old (1964), Oodgeroo's first poetry collection entitled 
We Are Going was first published. The poetry is full of the images of the Aborigines' predicament as the effects of British colonization. The poetry portrays a strong sentiment about the injustice and misery inflicted upon them. Heiss (2006) states that We Are Going met with great sympathy and understanding on the part of the white community. We Are Going helps people to see the distress of indigenous Australian Aboriginal caused by British colonialism through the Aboriginal people's eyes.

As an Aboriginal descent, Oodgeroo faces several difficulties in her life. Woods (2010) states that in her 13 years old, Oodgeroo started working as a domestic servant in people's houses. While at the age of 16, she wants to pursue her dream to be a nurse, but she was rejected in the first training because she is an Aboriginal descent. Since then, Oodgeroo decided to become a member of the Australian Communist Party in 1961 to face the inadequacy of the established political parties, in particular their failure to fight Aboriginal issues and rights. A short time later, she took a position as secretary of the Queensland State Council for the Advancement of Aboriginals and Torres Strait Islanders and served in that post until 1970. The hard-fought campaign resulted in the history-making 1967 Referendum. Australians voted overwhelmingly to include Aboriginal people in the census and to ensure they were covered by Commonwealth laws (Abbey, 2017).

In 1964, when her poetry collection We Are Going was first published, it began a new phase in communication and relations between black and white Australia. Since then, Oodgeroo commits to use her writing as the weapon to voice her voiceless people. According to Iswalono (2004), Oodgeroo's poetry portrays how Aboriginal people who are the nature of the land are made 'strangers' by the white tribe who are themselves the true strangers to the land.

Poetry, by definition, is one of the literary forms related to any kind of verbal or written language that is structured rhythmically and is meant to tell a story or express any kind of emotions, ideas, or state of being. According to Wolosky (2001), poetry is a language that always means more. The poem's subject might be the poet's protest, satires, or a description of something else. A poet mostly tends to use not commonly language to attract people and get their curiosity to take a look at the poetry in a more in-depth way by connecting the poetry with the background of the poet or the event that happened during the time where the poetry was written. Based on the explanation above, we can say that poetry is the tool or weapon for Oodgeroo to voice what she wants to share with others.

Understanding the main themes of Oodgeroo's poems, which deal with the struggles and effects of colonization and how her poetry used as the voice of voiceless Aborigines, could give inferences that Oodgeroo's poems can be analyzed through post-colonialism in Gayatri Chakravorty Spivak perspective relating to Subaltern. Basically, Spivak's theory concept of Subaltern is to deal with 'the voiceless party.' Her essay Can the Subaltern Speak? which actually a commentary on the work of The Subaltern Studies Group formed by Ranajit Gaha, she is questioning and expressing their patronizing attitude. Subaltern is originally a military term, which meant lower rank. She borrowed this term from Italian 
Marxist Antonio Gramsci. In her essay, Can the Subaltern Speak? shows the earliest political historiography shifts the voice of subaltern groups (Praveen, 2016).

In postcolonial criticism itself, the word subaltern refers to a member of any group who faces oppression due to caste or gender or race. According to Spivak (1889) subaltern is a position without identity. In other words, subalterns are considered as the group of people who are not able to represent themselves as a class or social group in elite historiography. The term subaltern refers to group marginal and are at the inferior level accept hegemony and repression from dominant parties. This group is in position who are depressed and have no room for voiced their aspirations.

From the explanation above, the researcher wants to analyze Oodgeroo Nonuccal's selected poems by using post-colonialism in Gayatri Chakravorty Spivak's perspective of Subaltern. The selected poems are We Are Going, Aboriginal Charter of Rights, and The Dispossessed. After reading the selected poems, the researcher found that the poems comprise the idea of Aborigines' silence then exploited by the colonists' power as the superior party.

Meanwhile, the research about both of Oodgeroo's poetry and Subaltern have been executed by some previous researchers. The first is Iswalono (2012) that examines the relation of We Are Going with the land right faced by the Aborigines. Second, Furaih (2018) that examines similarities in Oodgeroo and Sanchez's poetic themes due to a general awareness of a global movement of black resistance. Third, Ounkwo and Nweke (2016) investigate the poetics of race in Lorde and Oodgeroo's poems. The fourth research is Nurfadhillah (2019) that explores the subalternity of the colonized party in Agnes Jessica's Sang Maharani.

Based on the research questions above, the objective of this research is to find out the Subalternism portrayed in Oodgeroo's selected poems, We Are Going, Aboriginal Charter of Rights, and The Dispossessed. It also aims at finding out the relation between Subalternism in the history of Aborigines and Oodgeroo's selected poems.

This research is a literary criticism. The researcher applies the concept of Subaltern by Gayatri C. Spivak to conduct the discussion and analysis on literature by focusing to the concept of subalternism portrayed in Oodgeroo Noonuccal's selected poems. The selected poems are We Are Going, Aboriginal Charter of Rights, and The Dispossed. By the definition, literary criticism is the study, interpretation, and also evaluation of literature. In this case, literary criticism is the appropriate way to conduct this research in order to explain the Subalternism in the selected poems mentioned above.

\section{DISCUSSION}

\section{Subalternism Portrayed in Oodgeroo's Selected Poems}

\section{The Superior Domination and the Effects in Oodgeroo's Selected Poems}

The selected poems of Oodgeroo are full with the images of colonization through the colonized party's point of view. In this case, the colonized party refers to the indigenous people of Australian land, the Aborigines. In the poems, Oodgeroo illustrates the great 
predicaments experienced by the Aboriginal people in dealing with the British colonization and the effects of it. In dealing with the British colonization, the Aboriginal people have to experience a lot of physical, mental, and even sexual violence, which most of those cases are causing death.

The oppression of the superior party which is in this case is referring to British against the Aboriginal people as the inferior party arise by the conflict of the land rights. Different from the Aboriginal people who put a huge respect and value the land with the bond and spiritual beliefs, the British claimed the land by force and treated the land as the business field for gaining wealth.

The white man claimed your hunting grounds

and you could not remain,

They made you work as menials

for greedy private gain;

The words claimed your hunting grounds and made you work as menials from The Dispossessed illustrate how the British claimed the land and forcefully labored the indigenous people. The use of claimed and made words show the superiority of the British who hold domination over the indigenous people. As the British claimed the land, the Aboriginal are forced to both work for farming or as stockman without any reward or wages. All of the benefits of the forced labor of Aboriginal people belong to the colonial government.

From Spivak's perspective, the term of subaltern refers to marginal group who accept hegemony and repression from dominant parties in the inferior level. In this case, the position of the helpless Aborigines are considered as the inferior party who must accept repression from British as the superior party. The British colonists are seizing their sacred land and even force them to work on the land without any reward.

The presence of British colonists who are increasingly spread and seize their sacred land surely pushing off Aboriginal people continually from the land that belongs to them. Beside suffering from the oppression, the Aborigines also can not get the justice for their stolen rights.

Your tribes are broken vagrants now

wherever whites abide,

And justice of the white man

means justice to you denied.

As presented in this stanza from The Dispossessed, the lines justice of the white man means justice to you denied portray the reality that Aboriginal people are very difficult even can not to get justice for their predicaments which is not something they should receive. With the fact that Aboriginal people do not know about ownership business to the land, they considered the land as the part of their lives, culture, and spirituality. Then the British arrived and seize every precious things for them to gain wealth. Furthermore, the clear statements related with the status of the Aborigines as the dying race in this stanza can found in the next stanza: 
A dying race you linger on,

degraded and oppressed,

Outcasts in your own native land

you are the dispossessed

The words such as degraded and oppressed, outcasts, and the dispossessed are the terms that can not be separated from the lives of Aboriginal people. They are degraded and oppressed, as their precious sacred land is used as a business field for worldly gain. Their beliefs are underestimated and tried to be replaced by the religion the colonists brought. Their young generation is separated from the families and forced to forget their Aboriginality as the true identity. They are the outcasts, as they are marginalized and pushed off from their land with advanced weapons that ready to kill them at any time.

Furthermore, Spivak also points out in the matter of subject who depressed or generally located inferior level as subaltern group. In this case, the Aborigines are always in inferior position and get depression as the strangers give them inhumanly oppression and claim their land without any respect to them as the true indigenous people to the Australian land. As the effects of the oppression, the indigenous people inevitably have to live as strangers in their own land. As portrayed in the lines from We Are Going:

'We are as strangers here now,

but the white tribe are the strangers.

We belong here, we are of the old ways.

In this line, 'We are as strangers here now illustrates how the Aborigines slowly lost their livelihoods and their identity as indigenous people. At first, the conflict of land rights unavoidably led to conflict, often violent, as Aboriginal people tried to resist the dispossession as best as they could. However, their resistances led to the massacres. the Aboriginal people must lose their rights as human also as the indigenous of the land, they lose the sacred land which has an important connection with their spirituality, and they also lose their families and generations of Aboriginal tribe. The true strangers are successfully pushed off the true native from their sacred land.

Furthermore, considered as the colonized party, Aboriginal people seem to lead their new life that will never be as comfortable and peaceful as the days before the arrival of British colonists.

We need help, not exploitation,

We want freedom, not frustration;

Not control, but self-reliance,

Independence, not compliance,

Not rebuff, but education,

Self-respect, not resignation

In this stanza which from The Aboriginal Charter of Rights, the words such as the exploitation clearly aimed to the massacres of Aboriginal people. The massacres began in 1794 by the members of British colonists, then flourished to involve the local officers and settlers under the command of British colonial government. In 1806, the more severe 
slaughtering began, Aboriginal children were abducted for forced labour, women were raped and abused, and men were shot. The people were killed intentionally with the reason because they are Aboriginal people. The British colonial government were continuously involved in frontier massacres until at least the late 1920s.

While the frustration, control, and compliance words related with how the Aboriginal people can not live their lives freely. They have to obey the laws established by the colonial government and even threatened with physical violence or even killed if they are considered to have done what is prohibited by the laws. The colonial government managed to control the lives of the remaining Aboriginal people by spreading stories that seemed to conceal the predicaments of the colonized party and even took over the media to decrease their negative image.

There is a story told that the Aboriginal people willingly gave the land because they can not value it properly. However, the story was intentionally spread to conceal and legitimately defend the illegal colonization by British. Moreover, the colonial government take over the media which have played a part in misrepresenting the facts by reporting the case as if the Aborigines were just settlers in the land of Australia and not the real indigenous. In other case, according to Roberts (2008) The Aboriginal Protection Act (1869) declared to give Aboriginal people protection, but instead they give the British the power to seize the land.

As mentioned before, the indigenous people of Australian land are treated as the subject of the British colonists. They unhesitatingly dominating and ruling on Aboriginal people land.

Free us from a mean subjection,

From a bureaucrat Protection.

Let's forget the old-time slavers:

Give us fellowship, not favours;

Encouragement, not prohibitions,

Homes, not settlements and missions.

In this stanza from Aboriginal Charter of Rights, the lines illustrate how the Aboriginal people found it difficult to get the freedom of their lives. They were driven from their land, placed in settlement camps, forced to comply the laws made by the colonial government, and surrounding by the domination of the British colonists. The lives of Aboriginal people seem to be inseparable from the subjection and parties that engaged under British government's command which aimed to facilitate the occupation. The untrue stories spread by the colonists, manipulation played by the media, and even the communities that claimed themselves as the protector for the Aborigines are actually used to restrict the movement of Aboriginal people who began the attempt to take a higher resistance.

The fact is, in their previous lives, Aboriginal people always maintain peace in their lives. They are not too fond of conflict which will only cause injury and blood in the brotherhood in their sacred land. The Aboriginal people put a huge respect and value the 
Australian land. However, the arrival of British destroyed the peace in the Australian land. As portrayed below:

We need love, not overlordship,

Grip of hand, not whip-hand wardship

Opportunity that places

White and black on equal basis.

In this stanza from Aboriginal Charter of Rights, the words such as overlordship and whiphand wardship represent the British domination and oppression towards Aboriginal people. From the beginning of their arrival, the British consider the indigenous people as savages and primitive people. As mentioned before that British hold a strong dominant position in the world in the eighteen century for their advanced technology, seafaring, and great military. Because of that, the British do not want to put any respect to the land and Aboriginal people who are the true native of the land. Meanwhile, the Aboriginal people do not really have prejudice toward British colonists because they thought those white people would only stay for a while and would go on their way. The Aboriginal people decided to help the colonists to survive in their land even guide them where they could find good water.

In the opening stanza of Aboriginal Charter of Rights, it mentions the other effects of the British colonization.

We want hope, not racialism,

Brotherhood, not ostracism,

Black advance, not white ascendance:

Make us equals, not dependants

The lines mentioned racialism, ostracism, and dependants as the things that certainly experienced by Aboriginal people. Racialism and ostracism are something that has been obtained by the indigenous people from the beginning of the oppression in their land. They were considered as a dying race who have no power to defend their rights and the land. The negative stereotypes also aimed to the Aborigines spread by the British colonists who said that Aborigines are primitive and violent, lazy, even alcoholics. In fact, Aboriginal people teach the moral values such as gratitude to the land and respect to the elders. They are frowning on violence particularly against women and children. They are also far from the term lazy, since hunting, practicing their culture and hunting, are some of the things that become their daily activities.

The issues relating to racialism and ostracism are still not disappearing and even many of Aboriginal people are experiencing it in the twentieth century. As Paradies et al. (2008) state that the racial discrimination experienced by Aboriginal people is resulting stress and depression then ended up causing poor both of mental and physical health. As the effect of British colonization, racialism is being one of the most burdensome for their psychological health. Meanwhile, the Black advance, not white ascendance and Make us equals, not dependants lines represent the social oppression that degrading the status of Aboriginal people as a race that is always beneath the supremacy of white people. 
In the next stanza, the lines put sarcasm towards those who should help and defend the Aborigines:

You dishearten, not defend us,

Circumscribe, who should befriend us.

Give us welcome, not aversion,

Give us choice, not cold coercion,

Status, not discrimination,

Human rights, not segregation.

The lines You dishearten, not defend us and Circumscribe, who should befriend seem to question the parties who should have enough power to help them defend themselves. However, the great power and influence of British at that time precisely attract many parties choose to side with them. In this case, as mentioned before, The Aboriginal Protection Act is one of the parties that decide to side colonial government. They declared to give Aboriginal people protection in dealing with British colonization, but instead they give the British the power to seize the land. It shows how the parties are expected to be able to help but instead ignore the lives of Aboriginal people who are in a very difficult situation.

The other words such as aversion, cold coercion, and discrimination are some of the social pressure faced by Aboriginal people as the effect of British colonization. The Aborigines unfairly receive such treatments by the reason that they are Aboriginal descent. Meanwhile the segregation refers the agenda of the Stolen Generations, this term is used to describe the forced separation of Aboriginal children from their families. The reason of the Stolen Generations is to end the chain of the Aboriginal tradition that has passed through generations and end up ruin the future of the Aboriginal community. As the result, the Aboriginal children are suffering from trauma and questioning their true identity as the British colonists attempt to remove their Aboriginality.

Besides separating the Aboriginal children from their parents that called as the Stolen Generations, the British also tried to spread Christianity religion that they believed in to the Aboriginal people.

Give us Christ, not crucifixion.

Though baptized and blessed and Bibled

We are still tabooed and libelled.

This lines represent how the British are trying to spread Christianity in the land of Australia when the Aboriginal people are still trapped in British domination which is often tinged with violence and even murder. The British can not understand the belief of Aboriginal people that based on philosophy of natural environment. The sacred ceremony and rituals are the way how the Aboriginal communicate with the ancestral spirits and spiritual world. That is why the Aboriginal people have a strong bond to their land. However, the British do not want to understand and respect the belief of Aboriginal people, they only considered that Aboriginal people are heathens so they need to convert the people to Christianity. 
Furthermore, the Aborigines are seen as a dying race, they were physically discriminated against, forcibly pushed off their lands and families, relocated to settlement camps and stations.

The scrubs are gone, the hunting and the laughter.

The eagle is gone, the emu and the kangaroo are gone from this place.

The bora ring is gone.

The corroboree is gone.

And we are going.

The line And we are going portrays the disappointment and frustration of the Aborigines. The closing line illustrates how desperate the Aboriginal people who found it difficult to get the justice and their rights as the indigenous of Australia, even inevitably have to be marginalized from their own land. The line And we are going is the actual irony of the indigenous lives that can not be saved from the predicaments and must leave their sacred land.

Considered as the inferior party, the Aboriginal people find it difficult to reach their freedom and get their land back under the white superiority.

Must we native Old Australians

In our own land rank as aliens?

Banish bans and conquer caste,

Then we'll win our own at last.

The lines Must we native Old Australians in our own land rank as aliens? are questioning the lives of Aboriginal people as their land is seized and being alienated from their 'home'. Their connection with the land is not only about as the resources for their lives, but it is crucially important for their religious beliefs as most of their cultural practices are linked to the sacred land. Thereby, the Aboriginal people believe that their true home is in the land of Australia, they belong to the land as it is where their ancestors are. However, the British colonization had ruined the Aborigines' lives since they had no attachment to land and only made it into a business field.

\section{Woman as Subaltern in Oodgeroo's Selected Poems}

The term woman have its own emphasis on Subalternism, it is considered by the reason that women who are included in a colonized party will get more cruel treatment and amore difficult to speak out remembering that women are considered as the weakest community. In this case, it can be said that women as subalterns are more silence and suffer more than the subaltern men.

Furthermore, the portrayal of woman as subaltern can be found in a line from The dispossessed that illustrates the Aboriginal women as helpless subaltern.

Peace was yours, Australian man,

with tribal laws you made,

Till White Colonials stole your peace

with rape and murder raid; 
the words with rape and murder raid is related with the terrible predicaments of Aboriginal women in the time of British colonization. The Aboriginal women are horribly suffering during the British colonization. The murder raid that following the rape word can be connected with how the British colonists treat Aboriginal women. They are taken away from their families and husbands then enslaved and raped. In the colonization time, the women are treated only as a place for lust for the colonists, even many of are not only raped but also sexually tortured. Because of the rape and sexual torture, many of Aboriginal women are abandoned to die from venereal disease or from cruel torture.

\section{The Voiceless in Oodgeroo's Selected Poems.}

The main problem in the study of subalterns is not only concerning about the categories of people who are oppressed or the oppressed working class, but also about anyone whose voice is limited by the access that try to represent it. The problem that must be emphasized in the subaltern initiated by Spivak actually refers to anyone who does not have freedom to speak or express themselves. Which means, those people who are always represented by the dominance of the discourse of power, especially in the post-colonial context.

In this case, the researcher finds the words that represent the voiceless subaltern in the selected poems. Such as in the first stanza of We Are Going, written below:

They came in to the little town

A semi-naked band subdued and silent

All that remained of their tribe.

The words subdued and silent represent Aboriginal people as the voiceless who can not speak and fight for their rights under the British domination. When the British began to seize their land, the Aborigines actually attempted to speak and resist but then they were tortured and killed cruelly. Since then, the Aboriginal considered as the weak and dying race with the fact that they were dealing with British who held a strong dominant position in the world in the eighteen century for their advanced technology, seafaring, and great military.

Another words that represent the voiceless can be found in one of the stanzas in The Dispossessed. In this stanza, the lines show how the Aboriginal people are being oppressed as their land is seized and they can not defend it, the words are written below:

The white man claimed your hunting grounds

and you could not remain,

They made you work as menials

for greedy private gain;

The words you could not remain clearly clarify the position of Aboriginal people as a weak party who can not defend themselves. The Aborigines are silenced in both of their voice of the claim of their seized rights and their physical resistance which have been decisively defeated by advanced weapons that even the Aborigines have never seen before. 


\section{Subalternism in the History of the Aborigines}

In this section, the researcher shows the history of British colonization and the effects against the Aboriginal people as subaltern group. At the day when the first arrival of British colonists, a group of Aboriginal people are gathering and fishing as usual, then they see the big white ship of British colonists that slowly approaching their cove. As seeing a group of white people wearing the type of clothing and weaponry that they had never seen as a threat, the group threw the ship with spears. The lieutenant James Cook then respond them with a shot which eventually wounded one man. The shooting then shocked the group and made them run away from the area, and at that very moment the British set foot on the land of Australia. After successfully meet and discuss with representatives from the Aboriginal people, the British then began to inhabit and build camps at the agreed border.

Seeing the indigenous people of the land are not strong enough to fight them, the British started to mark their movements to seize the land by spreading the declaration of the term of unhabited land or well known as terra nullius to the land. Then, the colonial government started to establish and spread their people from the initial boundaries and then pushed off the Aboriginal people from the land slowly. As the colonists established, Aboriginal people are started being pushed off from their own land. They started to lose their livelihoods, their cultural practices, and their family.

Physical conflict occurred between the colonists and Aboriginal people who try to speak to resist and defend their tribe and the land, but ended in the massacres and separation of women and children from their families. Desai (2015) states that James Cook claimed he wanted peaceful relationship with the Aborigines. However, the fact showed that from the beginning of their settlement, the British had a bad impression of Aboriginal people. In this case, the British colonists are actually not the first settler that stay over in Australian land and the Aboriginal people are always welcoming them without any problems or conflicts. Nevertheless, the problems arise when accepting the arrival of the British is actually such a big mistake for the Aboriginal people since it ends in great misery for their lives.

The Aboriginal people can not really voice their voices as the colonized party. Their voices and demands are can not be heard because of many parties deliberately manipulating their voices. It is stated by Desai (2015) that The Aboriginal Protection Act (1869) claimed themselves as the protector of Aboriginal people, but instead give the power to colonial government to seize the land, home, and children from the Aborigines. The expected protection aspect of the law covered almost all of the abuses and injustices toward Aboriginal people.

As marginalized and silenced group, the fate of subalterns are tend to be ignored and even forgotten. Being ignored in the context of life exacerbates the predicaments experienced by the subalterns who do not have the strength and access to show their true selves due to the strong dominance of the superior party. In this case, the Aboriginal 
people also experience how their lives are not considered as something important to the British colonists. The existence of Aboriginal people is only considered as an inferior race that can only be exploited by their labour to work for them.

The lives of Aboriginal people seemed to always be underestimated by the British colonists. This is proven by how the population of Aboriginal people was rapidly decreasing due to the separation of children and women, intentional slaughter, and diseases that spread by the colonists. For the example is the small-pox epidemic spread through around Sydney in 1789 and led to the death almost half of the Aboriginal population. The physical conflict that also led to more death caused by the massacres, about more than 10,000 were killed between 1824 until 1908. Before the colonization, the population of Aborigines was approximated to be 15,500 then decreased until only around 2,341 in 1861.

Furthermore, as the group of people who are oppressed and surrounded by representations and misrepresentations, the subalterns certainly experienced considerable difficulties in fighting the justice for their rights. In this case, the Aboriginal people find it difficult to achieve justice for their stolen rights as the indigenous people because of the British domination which at the time seemed to close all access to justice.

One of the examples is how the remaining Aboriginal people were not included in the Australian population census until 1900s. The census considered not attempting to include the Aborigines who were stayed outside the settlements. Furthermore, the national referendum in 1967 finally voted to change the Constitution to require the Aboriginal people to be included in the Australian census. The 1967 referendum seemed to be one of the landmarks for Aboriginal people which marked the achievements of their struggle in fighting their rights.

Moreover, Aboriginal people are oppressed in all aspects of their lives, from emotional, mental, social, to their spiritual which affect the lives of the remaining Aborigines in the future. As is known, the effects that attack the colonized party in psychological and social aspects will tend to last a long time and continue to haunt throughout their lives. In this case, the Aboriginal people as the oppressed and colonized party have psychological and social effects such as stress, depression, trauma, racism, and also discrimination. The Aboriginal people inevitably can not be free from those things easily.

Furthermore, the separation of the children from their family or well known as The Stolen Generation happened around 1890s until 1970s also take a role to give psychologically oppression towards the young generation. The children are separated from their family without any promise they would see and back to their families again. According to Creative Spirit (2014), since 1883 until 1969 it is approximated that more than 6,200 Aboriginal children were stolen. These children are restrained by the rules that strictly prohibit them from speaking in Aboriginal language. The British tried to end the chain of pure Aboriginal generations by indoctrinating the children so they would not act like Aboriginal people and some were adopted to white families. The British intentionally 
oppressing the Aboriginal young generation psychologically, so they can forget their identity as the Aborigines and ruin the future of Aboriginal people. Because of the agenda of The Stolen Generation, the children were questioning their true identity, experiencing trauma and low self-esteem.

Meanwhile, the Aboriginal women also faced terrible predicaments during the British colonization. The women as subaltern is much more silenced compared to men. Spivak considered women who are included in a colonized party will more difficult to speak out remembering that women are seen as the weakest community. A report in 1990 showed that Aboriginal women were enslaved and handed over from station to station to serve the British colonists. The Aboriginal women are taken from their families and husbands by force and were treated as sex dolls and then ended up being abandoned to rot away with sexually transmitted disease. The innocent women must experience inhumane treatments such as physical, mental, and also sexual violence until they are left to die at the end.

Furthermore, the socially oppression experienced by the Aborigines is mostly caused by the untrue stories and statements spread by the British colonists about the indigenous people. The untrue stories such as how violent, savage, and scary the Aboriginal people are or the statement tells that Aboriginal people are lazy, these prejudices seem to be hereditary and form negative stereotypes of Aboriginal people. That is why, the remaining Aboriginal people must get unpleasant treatments just because they are people with Aboriginal descent, even that still happens in the twentieth century. As Paradies et al. (2008) states that a survey conducted in 2001 found approximately 30 per cent of Indigenous people mentioned discrimination on the basis of ethnic origin. Some research in Australia also have shown that indigenous people who living in the cities, others who were members of the Stolen Generation, or those who identified as Aborigines are more likely to experience racism (Paradies et al., 2008).

\section{CONCLUSION}

The result of the study shows that subalternism is portrayed in Oodgeroo Noonuccal's selected poems entitled We Are Going, Aboriginal Charter of Rights, and The Dispossessed related to domination of the superior, women, and the voiceless. The first finding in The Superior Domination and the Effects in the Selected Poems, show that the British superiority led to their domination against Aboriginal people as the weaker party. It is resulting the great predicaments for the Aboriginal people who must lose their rights as human also as the indigenous of the land. The lives of the Aborigines are seen as something unimportant and end up treated cruelly continuously. As the effects of the colonization, the Aboriginal people inevitably have to leave their sacred land since they can not fight back and reach the justice of their rights, they become 'alien' in their own land. Beside that, the remaining Aboriginal people also must deal with the negative stereotypes, unfair and unpleasant treatments, depression, and trauma as the effects of British domination. 
The second, in Women as Subalterns in the Selected Poems show how women are considered as the weakest party, the subaltern women are helpless and more silenced compared to men. In this case, Aboriginal women are made as slaves by force to serve and satisfy the lust of the British colonists then ended in tragic deaths caused by venereal disease or caused by the sexual torture. Lastly, The Voiceless in the Selected Poems show how the Aboriginal people must live surrounding by representations and misrepresentations of the privileged parties who hold domination that makes it more difficult for them to get their rights. As subalterns, the Aboriginal people become a group who never speak or the voiceless, since they do not have the opportunity to voice their voices and their real voices can not be heard.

This research also provides the relation between the subalternism in the history of Aboriginal people and in Oodgeroo Noonuccal's selected poems entitled We Are Going, Aboriginal Charter of Rights, and The Dispossessed in the matter of Aboriginal people who positioned as the oppressed and voiceless party under British colonization. Additionally, This research also revealed that Oodgeroo Noonuccal is successfully speak for the Aboriginal people, the colonized race that considered as the subalterns. This is supported with the fact that she is an Aboriginal woman that can be said she is a subaltern woman who write poetry to voice her people with demands for justice and equality.

\section{REFERENCES}

Desai, Hawa. (2015) The Effect of Colonization on the Aboriginal People's Culture and Religion. Journal of Undergraduate Research. Volume 8 Issue 2.

Ezzeldin, Hend Hamed. (2017). (Un)Representations of the Subaltern in Three Victorian Novels. International Journal of Humanities and Cultural Studies. Vol 3 Issue 4.

Furaih, Ameer Chasib. (2018). 'Let no one say the past is dead': History wars and the poetry of Oodgeroo Noonuccal and Sonia Sanchez. Cambridge University Press. Volume

25 Issue 1 , pp. 163-176. DOI: https://doi.org/10.1017/qre.2018.14

Iswalono, Sugi. (2012). Aboriginal Land Rights Issue as Recorded In Oodgeroo Noonuccal's

"We Are Going". Volume 11, No 1. Retrieved 30 September, 2019, from

https://eprints.uny.ac.id/5054/1/

Mambrol, Nasrullah. (2016). Subaltern (Postcolonialism). Retrieved 27 October, 2019, from https://literariness.org/2016/04/08/subaltern-postcolonialism/

Ounkwo, C.M. and Nweke, C.A. (2016). Poetics of Race in the Selected Poetry of Audrey Lorde and Oodgeroo Noonuccal. International Journal of Social Sciences \& Humanities Review (IJSSHR). Vol 6, No 3.

Paradies, Y., Harris, R. \& Anderson, I. (2008), The Impact of Racism on Indigenous Health in Australia and Aotearoa: Towards a Research Agenda. Discussion Paper No. 4, Cooperative Research Centre for Aboriginal Health, Darwin.

Praveen, Ambesange V. (2016). Postcolonialism: Edward Said \& Gayatri Spivak. Research Journal of Recent Sciences. Vol. 5(8), 47-50. 
Roberts, J. (2008). Massacres to Mining: The Colonization of Aboriginal Australia. London: War on Want.

Spivak, GC. (1988). Can the Subaltern Speak?. In Cary Nelson and Lawrence Grossberg (eds). Marxism and the Interpretation of Culture London: Macmillan.

Varghese, CS. (2009). Gayatri Spivak's Theory of Subalternity. Shodhganga a reservoir of Indian thesis. Retrieved 30 September, 2019, from https://shodhganga.inflibnet.ac.in/bitstream/10603/22597/10/10

Welch, David M. (2017). Aboriginal Religion. Retrieved 6 Juni, 2020, from: http://www.aboriginalculture.com.au/religion.html

Woods, Amanda. (2010). Indigenous Identity, Oral Tradition, and the Land in the Poetry of Oodgeroo Noonuccal, Luci Tapahonso, and Haunani-kay Trask. Retrieved 30 September, 2019, from: http://thescholarship.ecu.edu/bitstream/handle/10342/3536/ 
106 I Wardatul Khoiriyah, Siti Masitoh, Sri Muniroch 